DOI https://doi.org/10.18551/rjoas.2018-11.33

\title{
THE IMPLEMENTATION OF THE USE OF VILLAGE ALLOCATION FUNDS FOR THE AGRICULTURAL SECTOR IN SOUTHWEST ACEH REGENCY OF INDONESIA
}

\author{
Maulana Ona \\ Meurandeh Village, Lembah Sabil District, Southwest Aceh \\ Agusssabti \\ Jl Prada-Lamnyong, Syiah Kuala District, Banda Aceh \\ Fajri \\ Tanjung Harapan, Syiah Kuala District, Banda Aceh \\ *E-mail: ona.maulana24@gmail.com
}

\begin{abstract}
Dana Desa (Village Allocation Funds) are funds sourced from the APBN (State Budget) allocated to villages transferred through the $A P B N$ and Anggaran Pendapatan dan Belanja Kabupaten (Regency Budget) and used to fund government administration, development administration, community development and empowerment of rural communities. There are 3 priority principles in the use of Village Allocation Funds: justice, village's priority needs and typologies. Village Allocation Funds can also be used to use natural resources in rural areas such as the agricultural sector. The Government of Southwest Aceh issued a regional policy in order to use village allocation funds for the agricultural sector whose budget allocation was taken from the village funds. But the reality is that the implementation of the use of village allocation funds for the agricultural sector is not managed properly and there are problems that the implementers face towards the Southwest Aceh policy program. Therefore, it is very important to review the process of implementation of the use of village funds in the agricultural sector in Southwest Aceh.
\end{abstract}

\section{KEY WORDS}

Implementation, village allocation funds, agriculture.

Village is a legal community unit that has jurisdictional territorial boundaries, which are authorized to regulate and manage the interests of the local community based on the origin and local customs that are recognized and respected in the National Government system and located under the Regency / City Goverment. (Law No.32 of 2004 concerning Regional Government). This means that the village is an independent government within the subsystem of the National Government in Indonesia.

Based on data from the Ministry of Internal Affairs, there are 74,754 villages in Indonesia starting from Sabang Island to Meurake Island (Minister of Home Affairs Regulation Number 56 of 2015 concerning Code and Data of Government Administration areas). With that large number of villages, this proves that the village as the smallest unit within the National Government has an important role in the development of the Indonesian.

Therefore, to strengthen the role of the village in development, the Indonesian Government issued Law Number 6 of 2014 concerning village allocation funds. Village allocation funds are funds sourced from the APBN (State Budget) allocated to villages transferred through the APBN and Anggaran Pendapatan dan Belanja Kabupaten (Regency Budget) and used to fund government administration, development administration, community development and empowerment of rural communities.

In the use of village allocation funds, there are three principles of priority in the use of village allocation funds: (1) justice; prioritizing the rights and interests of all villagers without discriminating, (2) priority needs; prioritizing village interests that are more urgent, more needed and directly related to the interests of most of the villagers, and (3) village typology; 
taking into account the specific conditions and characteristics of the geographical, sociological, anthropological, economic and ecological characteristics of the village and changes or developments in the village's improvement. Therefore, the village allocation funds will strengthen the village's philosophy that is improving the welfare and equity of rural development through improving public services in the village, improving the village economy, overcoming inter-rural development gaps and strengthening rural communities as the subject of the development of this country.

The village allocation fund will strengthen the village's philosophy; increasing the welfare and equity of rural development through improving public services in the village, advancing the village economy, overcoming inter-village development gaps and strengthening rural communities as the subject of the country's development. The Southwest Aceh is one of the regencies in Aceh Province; the regency is located in the south west side of Aceh Province, which is the agricultural producing region in Serambi Mekah (Aceh).

Southwest Aceh have received village allocation funds for three years, from 2015 to 2017, from the first year to the third year the village allocation funds have increased. The increase will encourage rural economic development to be better for the welfare of rural communities within the regency.

Table 1 - Amount of village allocation funds transferred in Southwest Aceh Barat Regency (2015-2017)

\begin{tabular}{|c|c|c|c|c|}
\hline \multirow{2}{*}{ No } & \multirow{2}{*}{ District } & \multicolumn{3}{|c|}{ Total Amount of Village Allocation Funds Each Year } \\
\hline & & 2015 & 2016 & 2017 \\
\hline 1 & Lembah Sabil & Rp 3,799,998,620 & Rp.11,412,001,878 & Rp.14,855,485,000 \\
\hline 2. & Manggeng & Rp.5,366,524,218 & Rp. $15,796,891,153$ & $\mathrm{Rp}, 18,915,435,000$ \\
\hline 3. & Tangan-Tangan & Rp. $4,838,153,490$ & Rp.15,120,573,267 & Rp, 16,789,391,000 \\
\hline 4. & Setia & Rp. $1,917,088,523$ & Rp. $5,855,656,756$ & $\mathrm{Rp}, 9,563,175,000$ \\
\hline 5. & Blang Pidie & Rp. 5,955,799,964 & Rp. $17,444,045,834$ & Rp, $20,942,156,000$ \\
\hline 6. & Susoh & Rp. 8,772,664,182 & Rp. $25,435,873,202$ & Rp.,30,129,777,700 \\
\hline 7. & Jeumpa & Rp. $5,664,362,316$ & Rp. $10,795,640,860$ & $\mathrm{Rp}, 13,846,031,000$ \\
\hline 8. & Kuala Batee & Rp. $5,774,091,961$ & Rp. $17,788,198,982$ & $\mathrm{Rp}, 22,829,748,000$ \\
\hline 9. & Babahrot & Rp. $2,458,734,703$ & Rp. $9,280,092,967$ & $\mathrm{Rp}, 16,544,634,000$ \\
\hline Total & & Rp. 44,547,417,977 & Rp. $128,928,974,899$ & Rp.164,415,882,700 \\
\hline
\end{tabular}

Source: Dinas Pemberdayaan Masyarakat, Pengedalian Penduduk Dan Perlindungan Perempuan Kabupaten Aceh Barat Daya (Department of Community Empowerment, Population Control and Women's Protection in the Southwest Aceh).

Based on the village typologies within Southwest Aceh, the villages there rely on the agricultural sector as their rural economic base. So the Southwest Aceh government issued a regulation on the use of village allocation funds for the agricultural sector where each village allocates few percents of the village allocation funds for the agricultural sector based on the submission from the village community in order to help the village community who work as farmers in conducting agricultural business within in the villages.

The village allocation funds in the agricultural sector has been running for three years in the Southwest Aceh, where each village allocates funds in different amounts depending on the village apparatus submission in accordance with the village allocation fund and the amount of agricultural land owned by the village community. In the implementation of the regent's regulation regarding the use of village allocation funds for the agricultural sector has not been carried out in accordance with the expectations of the local government of 
Southwest Aceh where there are difficulties that must be faced by the executive officer in carrying out the regulations.

In tht case, in implementing the regulation on the use of village allocation funds for agriculture, it takes the role of the executive officer as well as the participation of the village community in the process of implementing the program, both from the process of submitting the allocation to the distribution process of village allocation fund to the agricultural sector so that the program can run optimally and on target.

\section{METHODS OF RESEARCH}

This research was conducted in the Southwest Aceh, precisely in two districts, Manggeng and Lembah Sabil by taking samples in eight villages. In Manggeng there are four villages that became the research area, Sejahtera, Pante Pirak, Ujung Padang and Pante Raja. In Lembah Sabil there are four villages that became the research area, Ladang Tuha II, Alue Rambot, Meunasah Sukon and Meunasah Tengah.

According to Sugiyono (2012), population is a generalization area consisting of objects or subjects that have certain qualities and characteristics set by researchers to be studied and then drawn conclusions. The populations in this study were the executors involved in the policy program on the use of village allocation funds for the agricultural sector in Southwest Aceh consisting of the Heads of Agencies involved in the program, the Camats and the Village Heads and the village facilitators consisting of counterpart experts district, district facilitators and local village assistants.

According Sugiyono (2014), sample is part of the sum and characteristics possessed by the population. In this study, the sampling technique used was random sampling; a sample selection method where each sample selection in the population has the same probability to choose from. In sampling proccess, the researcher uses a multi-stage sampling technique; a multi-stage sampling technique is a random sampling technique that is carried out in stages ranging from the highest level to the lowest level.

This study uses a qualitative approach, which in this study is descriptive; a research that is limited in efforts to express a problem, situation or event by conducting in-depth interviews conducted. Descriptive method according to Arikunto (2010) is a research method that is intended to investigate the circumstances, conditions or other things that have been mentioned, the results of which are presented in the form of research reports or descriptions of research conditions.

\section{RESULTS OF STUDY}

Village Development is aimed to improve the welfare of the villagers and their quality and poverty alleviation through the fulfillment of basic needs, the development facilities and infrastructure, the development of local economic potential, and sustainable use of natural and environmental resources. So in establishing the village, it cannot be separated from the issue of the village budget as one of a support in the framework of the village development activities. Therefore, the Law Number 6 of 2014 concerning Villages, is a legal protection for the village government in carrying out their duties and functions in the development proccess. In that Law, stated the village allocation funds for each village in Indonesia and considered as a new stage of village development in overcoming the development gap between urban and village.

The benefits of the village allocation funds are:

- Improve public services;

- Alleviate poverty;

- Advancing the village economy;

- Overcoming the gap between villages and inter-village development;

- Strengthening rural communities as the subject of development.

The Southwest Aceh government made one of the regional policies related to the village funds; the use of village allocation funds for the agricultural sector, this is one way to 
help the people of Southwest Aceh who are mostly become farmers, in improving their welfare, where the policy of using village funds for the agricultural sector is already running from 2015 to 2017 where the Southwest Aceh overnment has issued three regulations regarding the policy, namely:

- Regent Regulation of Southwest Aceh No. 14 of 2015;

- Regent Regulation of Southwest Aceh No. 7 of 2016;

- Regent Regulation of Southwest Aceh No. 23 of 2017.

Based on the Regulations of the Southwest Aceh Regent, the village allocation funds for the agricultural sector are allocated in each village with a certain amount without any compulsion for the village to allocate the funds or the village refuses to allocate the funds for the agricultural sector, all depends on deliberation what is done by the village apparatus with the villagers.

Table 2 - Village allocation funds for the agricultural sector in 2016-2017 in Southwest Aceh

\begin{tabular}{lllll}
\hline No & Program Type & Location & Year & Allocated Funds \\
\hline 1 & Procurement of Fertilizer and Rice Seeds & Southwest Aceh & 2016 & Rp. 1,739,168,134 \\
2. & Procurement of Fertilizer & Southwest Aceh & 2017 & Rp. 6,227,420,339 \\
3. & Procurement of Corn Seeds & Southwest Aceh & 2017 & Rp. 785,000,000 \\
\hline
\end{tabular}

Source: Program Pembangunan dan Pemberdayaan Masyarakat Desa (Village Community Development and Empowerment Program; P3MD) of Southwest Aceh.

Based on the table above, in 2016, villages that allocated the village funds for the agricultural sector for all region of Southwest Aceh as much as Rp. 1,739,168,134 allocated in the form of seeds and fertilizer. In 2017 village allocation funds for the agricultural sector increased to Rp. 6,227,420,339 allocated for fertilizer types and in that year also allocated for procurement of corn seeds as much as Rp.785,000,000 for Southwest Aceh.

Village allocation funds for the agricultural sector. A regional government policy program will not be separated from the budgeting problem of funds that will be used in the program that will be made, the better the budget allocation made by policy makers and implementing the policy, the bigger the impact of the program on policy recipients. Allocation of funds in a program must also be adjusted to the ability of available funds, not only that the program is prioritized until other fields that require these funds cannot be empowered.

In this study there were eight villages in two districts which were the object of research in the implementation of the use of village alllocation funds for the agricultural sector. In the Manggeng there are four villages that became the research area, Sejahtera, Pante Pirak, Ujung Padang and Pante Raja. In Lembah Sabil there are four villages that became the research area, Ladang Tuha II, Alue Rambot, Meunasah Sukon and Meunasah Tengah.

The use of village allocation funds for the agricultural sector is a budgeting process for village funds for the agricultural sector in which there are villages whose source of funds comes from village funds and the determination of the allocation amount is based on village deliberations conducted by the village government and the villagers and adjusted according to the applied Law and Regional Regulation.

In the table above explained that the village allocation fund for the agricultural sector is categorized in varying amounts, in Manggeng in 2016 the bigger allocation of the funds for the agricultural sector is Sejahtera with the amount of Rp. 40,000,000 and Ujung Padang with the amounts of Rp. 25,0000 000. However, in 2016 Pante Pirak and Pante Raja did not allocate funds for the agricultural sector. Whereas in 2016 Lembah Sabil in 2016 only three villages allocated the funds, Alue Rambot, Meunasah Sukon and Meunasah Tengah but Ladang Tuha I/ did not allocate village funds for the agricultural sector in that year. But in 2017 all villages in the study area allocated village funds for the agricultural sector.

From the data above shows that not all villages allocate the funds for the agricultural sector. Basically, all depends on the village deliberations conducted between the village government and the villagers. In addition, the amount of village funds allocated to the agricultural sector is also different among villages, but based on the data above, there is an 
increase in the amount of village funds allocated to the agricultural sector in the villages in the study area.

Table 3 - Village Allocation Fund Usage in Manggeng and Lembah Sabil

\begin{tabular}{|c|c|c|c|c|c|}
\hline No & Program Type & Districts & $\begin{array}{l}\text { Locations } \\
\text { (Villages) }\end{array}$ & $\begin{array}{l}\text { Time } \\
\text { (Year) }\end{array}$ & Budgets Allocation \\
\hline \multirow[t]{8}{*}{1.} & Procurement of & Manggeng & Sejahtera & 2016 & Rp.40.000.000 \\
\hline & Fertilizer and Rice & Manggeng & Pante Pirak & 2016 & - \\
\hline & Seeds & Manggeng & Ujung Padang & 2016 & Rp. $25,000,000$ \\
\hline & & Manggeng & Pante Raja & 2016 & - \\
\hline & & Lembah Sabil & Ladang Tuha II & 2016 & - \\
\hline & & Lembah Sabil & Alue Rambot & 2016 & Rp, $25,200,000$ \\
\hline & & Lembah Sabil & Meunasah Sukon & 2016 & Rp. $23,015,875$ \\
\hline & & Lembah Sabil & Meunasah Tengah & 2016 & Rp. $17,920,000$ \\
\hline \multirow[t]{8}{*}{2.} & Procurement & Manggeng & Sejahtera & 2017 & Rp. $77,200,000$ \\
\hline & Fertilizer & Manggeng & Pante Pirak & 2017 & Rp. $110,000,000$ \\
\hline & & Manggeng & Ujung Padang & 2017 & Rp. $72,000,000$ \\
\hline & & Manggeng & Pante Raja & 2017 & Rp. 50.800 .000 \\
\hline & & Lembah Sabil & Ladang Tuha II & 2017 & Rp. $61,613,000$ \\
\hline & & Lembah Sabil & Alue Rambot & 2017 & Rp. $41,500,000$ \\
\hline & & Lembah Sabil & Meunasah Sukon & 2017 & Rp. $30,906,000$ \\
\hline & & Lembah Sabil & Meunasah Tengah & 2017 & Rp.21.000.000 \\
\hline \multirow[t]{8}{*}{3.} & Procurement & Manggeng & Sejahtera & 2017 & Rp. 5.000 .000 \\
\hline & Corn Seeds & Manggeng & Pante Pirak & 2017 & Rp. 5.000 .000 \\
\hline & & Manggeng & Ujung Padang & 2017 & Rp. 5.000.000 \\
\hline & & Manggeng & Pante Raja & 2017 & Rp. 5.000 .000 \\
\hline & & Lembah Sabil & Ladang Tuha II & 2017 & Rp. 5.000 .000 \\
\hline & & Lembah Sabil & Alue Rambot & 2017 & Rp. 5.000 .000 \\
\hline & & Lembah Sabil & Alue Rambot & 2017 & Rp. 5.000 .000 \\
\hline & & Lembah Sabil & Alue Rambot & 2017 & Rp. 5.000 .000 \\
\hline
\end{tabular}

Source: Program Pembangunan dan Pemberdayaan Masyarakat Desa (Village Community Development and Empowerment Program; P3MD) of Southwest Aceh.

The amount of village funds allocated by the village to the agricultural sector varies in number, but the current problem is that if the amount allocated is sufficient for the needs of the village community or not. If all village funds are allocated to the agricultural sector, what about other fields that require village funds as well. This problem must be regulated by the village apparatus as the village government who is authorized to regulate the village fund allocation so that each sector's allocation in the village fund can be adjusted properly so that the use of village funds can be used for the welfare of the village community.

Table 4 - Results of interviews with village heads in the study area regarding the adequacy of village allocation funds for agricultural sector

\begin{tabular}{llc}
\hline No & Villages & Village Allocation Funds for Agricultural Sector \\
\cline { 3 - 3 } 1. & Adequate & Inadequate \\
& Manggeng District & $\mathrm{v}$ \\
& Sejahtera & $\mathrm{v}$ \\
& Pante Pirak & $\mathrm{v}$ \\
& Ujung Padang & $\mathrm{v}$ \\
& Pante Raja & $\mathrm{v}$ \\
2. $\quad$ Lembah Sabil District & $\mathrm{v}$ \\
& Ladang Tuha II & $\mathrm{v}$ \\
& Alue Rambot & $\mathrm{v}$ \\
\hline
\end{tabular}

Source: Interviews with village heads in the study area.

Based on interviews with village heads within the study area, it was known that the amount of village allocation funds for the agricultural sector had not been sufficient for their villages, because the amount of village allocation fund allocations for the agricultural sector 
had not been sufficient for their agricultural needs, as well as the vast amount of agricultural land cultivated by the villagers. It is inversely proportional to the amount of village allocation fund for the agricultural sector in their village.

Coordination. In implementing the use of village funds, a good coordination is needed between the implementers (executive officers), because coordination has an important role in conveying, directing and determining the direction of the program policy for the use of village allocation funds in general. Coordination between implementers starts from the budget allocation planning process that is budgeted, the process of submission from village to district, the process of disbursing village funds, as well as the activities of distributing village funds to the agricultural sector to the community.

Coordination has an important role in carrying out a government program policy that has been determined. The role is divided according to the respective duties and functions in accordance with the direction of policy makers in the area. In the policy of using village funds for the agricultural sector in the Southwest Aceh, good coordination is needed between the parties related to the village funds, because if the misuse of the village funds will be fatal and harm the community in the village. The implementing party must be able to coordinate well with those who oversee the village funds.

There are 3 forms of coordination carried out in the implementation of the use of village funds to run according to the target to be achieved.

Horizontal Coordination; the coordination of cooperation in harmonious and synchronous way between equal institutions. So horizontal coordination on the program for the use of village funds for the agricultural sector is coordination between the Dinas Pemberdayaan Masyarakat dan Desa (Community and Village Empowerment Service; PMD), Pengendalian Penduduk dan Keluarga Berencana (Population Control and Family Planning; PPKB), Pemberdayaan Perempuan dan Perlindungan Anak (Women's Empowerment and Child Protection; P3A) which is mandated by the regional government as the implementer (executive officer) in the program. As well as the accompaniment of the district level village experts as the party accompanying the implementation of the program to run in accordance with the regulations that have been set.

Vertical Coordination; the coordination of cooperation in harmonious and synchronous way from the higher level institutions to other institutions in the lower degree. Vertical coordination here is meant:

Coordination between the agencies dealing with village funds, Dinas Pemberdayaan Masyarakat dan Desa (Community and Village Empowerment Service; PMD), Pengendalian Penduduk dan Keluarga Berencana (Population Control and Family Planning; PPKB), Pemberdayaan Perempuan dan Perlindungan Anak (Women's Empowerment and Child Protection; P3A), Dinas Pemberdayaan Masyarakat dan Gampong (Community and Gampong Empowerment Service; DPMG) with all districts in Southwest Aceh involved in the process of socialization to the community about the regent's regulation on allowing the use of village funds for agriculture. Here is the role of the empowerment agency to coordinate with the district about how the system will be implemented in the district and its functions in implementing the implementation of the village funds program for the agricultural sector.

The sub-district then coordinates with the village head within his district about the socialization on allowing the use of village funds for the agricultural sector and the mechanism for budgeting village funds for the program.

Functional Foordination; coordination of cooperation in harmonious and synchronous way between institutions that have similarities in the work function. This coordination is occur between the village head and the village level facilitator and village fund supervisors so that the process in the implementation of village funds can proceed according to the applied regulations.

Forms and Models of Village Fund Distribution for the Agricultural Sector for the Community. The distribution of village allocation fund is the most important thing in the development and empowerment of rural communities, with the enactment of Law Number 6 of 2014 concerning villages that there are billions of rupiah of funds disbursed directly to the village sourced from village allocation fund which are part of the balance funds received by 
the Regency / City in Government Regulation Number 60 of 2014 concerning Village AllocationFunds sourced from the National Budget.

The agricultural sector is one of the priorities in the use of village allocation funds that aimed to strengthen Indonesian food sovereignty. In fact, there are still many cases of using village funds that are not right on target, such as corruption. Its misuse can also occur due to several factors such as villages not yet ready to manage the funds, lack of human resources, village governments that are not transparent and accountable. Therefore, it is necessary to do a number of things so that the use of village funds is on target, is by reforming or optimizing village government organizations, accountable and transparent village government, and budget oversight.

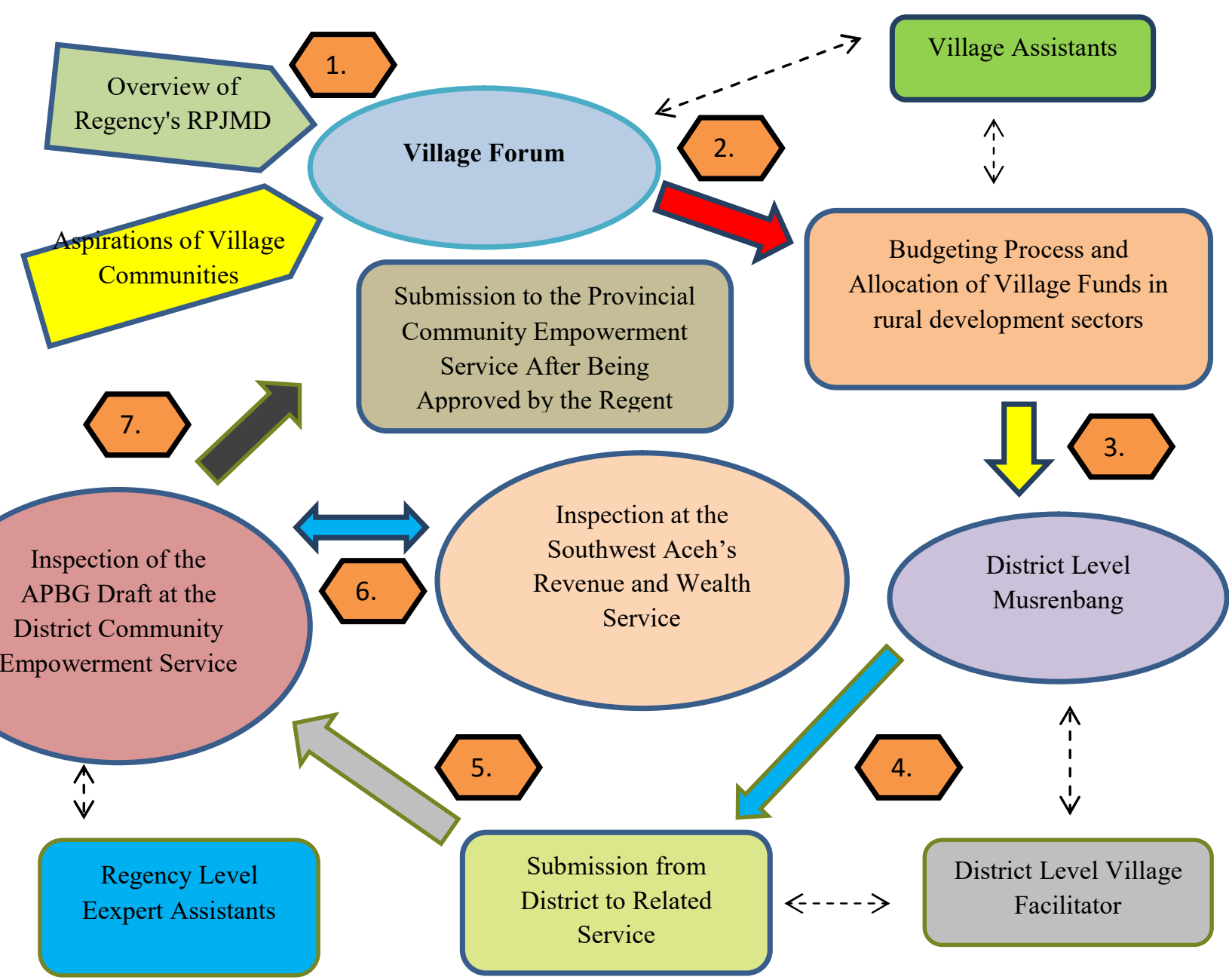

Figure 1 - Overview of the Planning Process in Village Allocation Fund for the Agricultural Sector in Southwest Aceh

The use of village funds for the agricultural sector is one form of economic empowerment for rural communities who own agricultural land. Community empowerment has a close relationship with sustainable development where community empowerment is a major prerequisite and can be likened to a train that will bring the community towards a dynamic economic, social ecological sustainability. Therefore, the strengthening of community empowerment in the regions needs to be carried out in a sustainable manner, because the community has shown that they have the will and desire to improve aspects of life both in the political, social and other sectors as evidenced by a critical attitude in responding to each symptom and actions of government officials and issues concerning development. 
The village head has an important role in empowerment development in the village, the village head is the smallest unit in the government and as the mouthpiece of the regency government in carrying out and continuing the policies that have been set by the government. Simply put, the role of the village head in enhancing community empowerment can be described; by carrying out a democratic life, by accommodating and channeling community aspirations in community empowerment programs, by preparing participatory planning activities, developing and enhancing self-help and mutual empowerment in development activities and exploring the available resource potential to improve development, by referring to PP No. 72 of 2005 concerning Village Heads in carrying out their duties, authorities, and responsibilities, namely carrying out a democratic life, coordinating village development in a participatory manner, empowering communities, enhancing the welfare of the community, developing natural resources potential, and develop community income.

The role of the village head regarding the use of village funds for the agricultural sector in Southwest Aceh is very vital, because from the process of submitting the use of village funds to the disbursement process as well as the accountability reports of the village head who do it, so that the implementation of local government policies can run well, various the method taken by the village head so that the assistance program for the use of village funds for the agricultural sector-fertilizer and seeds- can be right on target and not cause conflict among the community.

The role of the village head was done by holding meetings with the community and the village apparatus regarding the mechanism for distributing assistance programs for the use of village funds for the agricultural sector, which in average were in the form of fertilizers, there were village heads to divide according to the regent's regulations, like for the rice farmers, but it caused conflict in the village community.

There are several ways in which the village head's role in the distribution of assistance, there is distribution of assistance to the agricultural sector which is also based on the area of land in the village and based on the number of people working on agricultural land (sharecroppers) and the distribution based on the number of villagers who own agricultural land and manage the land the farm.

Other than that, there is a village head who distributes the aid program evenly to the village community without seeing their work. The important thing is that all the community can get the assistance even though in a small amount. Various reasons were expressed by the village heads so that they evenly distributed the aid even though it violated the existing regent's regulations and could not be on target in distributing it.

Table 5 - Model of Distribution of Support for Agriculture Sector from the Use of Village Allocation Funds in Southwest Aceh which is applied by village heads in the study area

\begin{tabular}{|c|c|c|c|c|}
\hline \multirow[b]{2}{*}{ No } & \multirow[b]{2}{*}{ Villages } & \multicolumn{3}{|l|}{ Model of Distribution } \\
\hline & & $\begin{array}{l}\text { Distribution For } \\
\text { Shrecropper Farmers }\end{array}$ & $\begin{array}{l}\text { Distribution for all } \\
\text { farmers (sharecroppers } \\
\text { and land owners) }\end{array}$ & $\begin{array}{l}\text { Even Distribution for Village } \\
\text { Communities Without Seeing } \\
\text { Their Work }\end{array}$ \\
\hline \multicolumn{5}{|c|}{ Manggeng District } \\
\hline 1. & Sejahtera & & v & \\
\hline 2. & Pante Pirak & v & & \\
\hline 3. & Ujung Padang & v & & \\
\hline 4. & Pante Raja & & v & \\
\hline \multicolumn{5}{|c|}{ Lembah Sabil District } \\
\hline 1. & Ladang Tuha II & & v & \\
\hline 2. & Alue Rambot & & $\mathrm{v}$ & \\
\hline 3. & Meunasah Sukon & & & v \\
\hline 4. & Meunasah Tengah & & $\mathrm{v}$ & \\
\hline
\end{tabular}

Source: Interviews with village heads in the study area.

From the data above, it is explained that almost the average village head distributes fertilizer which is one of the assistance from village funds for the agricultural sector to all farmers regardless of whether the farmers or the owners of rice fields whose have land all can be distributed. 


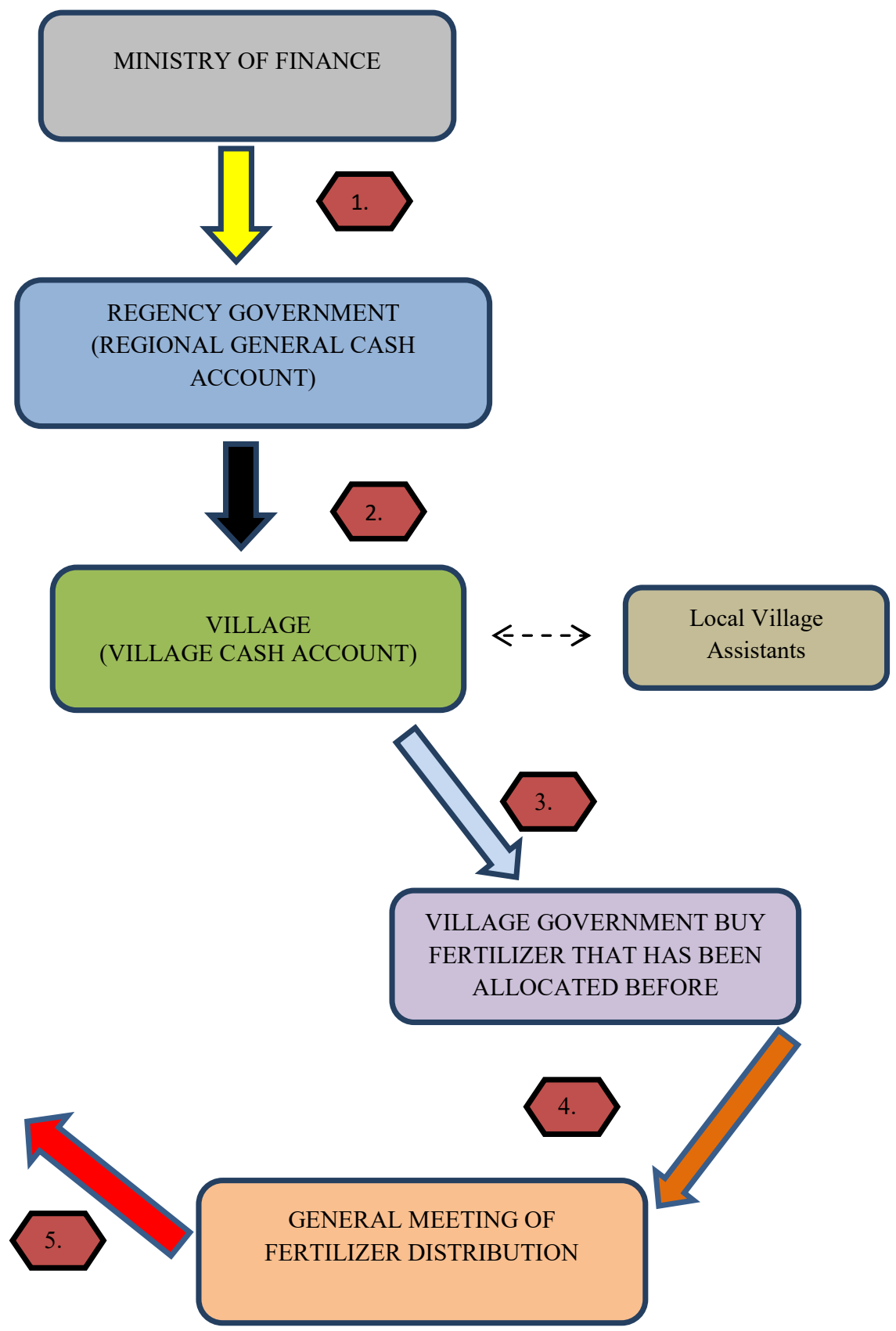

Figure 2 - Scheme for distribution of village funds for the agricultural sector in Southwest Aceh

The data also explained that only two villages distributed fertilizer from village funds only for farmers and only one village that distributed all the fertilizer to the villagers, to prevent turmoil in the community, then evenly distributed to the village community.

\section{CONCLUSION}

The amount of village allocation funds for the agricultural sector in Southwest Aceh increases every year but the allocation of funds was inadequate for the needs of the agricultural sector in the villages within the district.

Coordination between implementers (executive officers) of Southwest Aceh policy program on the use of village funds for the agricultural sector went well, so that the process of implementing local government policies went as expected. 
In the distribution process to the agricultural sector, the village allocation funds, the village heads distribute it in 3 ways according to the results of the general meeting between the village head, the village apparatus and the community so as to avoid social conflict in the village community.

\section{REFERENCES}

1. Abdullah, Syukur, 1988. Laporan temu kajian posisi dan peran ilmu administrasi dan manajemen, Jakarta: Lembaga Administrasi Negara Republik Indonesia dan asia Foundation.

2. Apriliani, Sherly Gresita, 2013. Akuntabilitas Pengelolaan Alokasi Dana Desa. Universitas Muhammadiyah, Malang.

3. AR, Nahfi Hanani. Dkk. 2002. Strategi Pengembangan Pertanian. PT Rineka Cipta, Jakarta.

4. Chambert, Robert.1997. Pembangunan Desa mulai dari belakang.LP3ES,Jakarta

5. Cravens David W. (1998) ". Implementation Strategies in the market-driven Strategy Era ". Journal of the Academy of Marketing

6. Dunn, W.N., 1992. Analisa kebijaksanaan publik, Yogyakarta: Hanindita graha widya.

7. Dye, Thomas R. 1978. Understanding Public Policy. New Jersey. Prentice Hall, Inc. Englewood Cliffs, N.J.

8. Fermana, Surya, 2009. Kebijakan publik sebuah tinjauan filosofis, Jogjakarta: Ar-ruzz.

9. Hartono, 2008. Pembangunan Partisipatif Masyarakat Desa Implementasinya Dalam Program Alokasi Dana Desa, Jawa Tengah: Malang.

10. Hariyanto Slamet, 2015. Dampak Kebijakan Alokasi Dana Desa (ADD) Terhadap Pembangunan Desa Di Kabupaten Bulungan Tahun 2011 - 2014.Umuha: Yogyakarta

11. Hudayana, Bambang dan Tim Peneliti FPPD, 2005, Peluang Pengembangan Partisipatif Masyarakat Desa Melalui Kebijakan Alokasi Dana Desa, Pengalaman Enam Kabupaten, makalah di sampaikan pada pertemuan forum pengembangan partisipasi masyarakat (FPPM) di Lombok Barat.

12. Kartika, Ray Septianis. 2015. Partisipasi Masyarakat Dalam Mengelola Alokasi Dana Desa (ADD) di Desa Tegeswetan Dan Desa Jangkrikan Kecamatan Kepil Kabupaten Wonosobo. Jurnal Bina Praja: Journal of Home Affair Governance. 4.3: 179-188.

13. Kementrian Hukum Dan Ham, 2014. Peraturan pemerintah, Jakarta: Kemenkumham RI.

14. Kementrian Pedesaan, 2014. Panduan Tentang Dana Desa, Kemdes, Jakarta.

15. LPD, Okta Rosalinda. 2013. Pengelolaan Alokasi Dana Desa (ADD) Dalam Menunjang Pembangunan Pedesaan (Studi Kasus: Desa Segodorejo dan desa Ploso Kere, Kecamatan Sumobito, Kabupaten Jombang). Jurnal IImiah.

16. Peraturan Menteri Dalam Negeri nomor 113 Tahun 2014 Tentang Pengelolaan Keuangan Desa.

17. Peraturan Menteri desa pembangunan daerah tertinggal dan transmigrasi nomor 22 tahun 2016 tentang penetapan prioritas pembangunan dana desa tahun 2017

18. Peraturan Pemerintah Nomor 43 tahun 2014 Tentang Peraturan Pelaksanaan Undang Undang Nomor 6 Tahun 2014 Tentang Desa.

19. Peraturan Pemerintah Nomor 60 Tahun 2014 Tentang Dana Desa Yang Bersumber Dari Anggaran Dan Pendapatan Belanja Negara.

20. Pressman, J.L, and Aaron Wildavsky. 1973. Implementation. University of California Press. Berkeley.

21. Putra, Chandra Kusuma, 2013. Pengelolaan Alokasi Dana Desa Dalam Pemberdayaan Masyarakat Desa (Studi Pada Desa Wonorejo Kecamatan Singosari Kabupaten Malang).Jurnal Administrasi Publik.

22. Setiawan, Guntur. 2004. Implementasi Dalam Biokrasi Pembangunan. Bandung: Remaja Rosdakarya.

23. Shaftitz, Jay M and E.W. Russel. 2005. Introducing Public Administration. Pearson Education Inc., New York.

24. Siagian, Sondang P. (2004). Manajemen Sumber Daya Manusi. Jakarta: Bumi Aksara. 
25. Soekartawi. 2002. Analisis Usahatani.Jakarta: Universitas Indonesia.

26. Subroto, Agus. 2009. Akuntabilitas Pengelolaan Dana Desa. UGM, Yogyakarta.

27. Sudaryanto,T dan Munif, A. 2005, Pelaksanaan Revitalisasi Pertanian, Jakarta: Agrimedia.

28. Sumodiningrat, G.2000. Visi dan Misi Pembangunan Pertanian Berbasis Pemberdayaan. IDEA, Yoyakarta.

29. Sugiyono. 2012. Metode Penelitian Kuantitatif Kualitatif, Bandung: Alfabeta.

30. Suryanto Hary 2011, Implementasi Program Peningkatan Kemandirian Perempuan Pedesaan Di Kecamatan Sumarorong Kabupaten Mamasa, Universitas Hasanuddin: Makassar.

31. Tiza Agustinus Longa, 2014, Implementasi Program Pembangunan Desa Mandiri Anggaran Untuk Rakyat Menuju Sejahtera. NTT.

32. Undang - Undang Nomor 6 Tahun 2014 Tentang Desa.

33. Wahab Solichin Abdul., 2008. Analisis kebijaksanaan, dari formulasi ke implementasi kebijaksanaan negara. Jakarta: Bumi aksara.

34. Wahab Solichin Abdul., 2008.Pengantar Analisis kebijakan publik, Malang: UMM press.

35. Winardi,1999, Pembangunan Indonesia,Bandung:Gramedia.

36. W.J.S.poerdwadarminta, 1997, Kamus Bahasa Indonesia, Airlangga: Jakarta. 